\title{
Investigating English Language Classrooms in Mexican Schools: The Issue of Entry and Access
}

\author{
Nora M. Basurto Santos and Paula Busseniers \\ School of Languages \\ Universidad Veracruzana, México
}

Received: 16 February 2011 / Accepted: 14 May 2011

ISSN: $1697-7467$

\begin{abstract}
This paper aims to contribute to the understanding of the process of gaining entry into Mexican English Language classrooms. After a very brief discussion of the basic concepts involved in the process of asking for permission to carry out research in educational settings, it then tells the story of our first-hand experience of gaining entry into public (and several private) preparatory schools in one city on the east coast of Mexico by starting at the top of the educational hierarchy at state level and working our way down into the actual English language classrooms. The paper finishes by raising some general issues that grew out of our anecdotal experience and that we claim may resonate or be helpful for other researchers approaching real EFL classrooms wishing to gain understanding of what is going on in practice in similar educational contexts.
\end{abstract}

Keywords: English language classrooms; fieldwork; negotiating access and entry; Mexico.

Una investigación en las aulas de inglés como lengua extranjera en centros mejicanos: El asunto de acceso

RESUMEN: En este artículo queremos compartir nuestras experiencias sobre aspectos claves al hacer trabajo de campo en salones de lenguas extranjeras en contextos educativos en México. Particularmente nos centramos en el proceso de negociación de acceso y entrada a las aulas, tanto públicas como privadas, en donde se enseña/ aprende el inglés como lengua extranjera. Desafortunadamente, en los estudios etnográficos que se han llevado a cabo en escuelas en México y que han sido publicados, este aspecto vital de la investigación cualitativa ha merecido, si acaso, una mínima descripción de qué y cómo se pudo, o no, conseguir el permiso. Reconocemos que, aunque cada contexto requiere de una aproximación única, creemos que nuestras experiencias resonarán y podrán ser de utilidad para nuevos investigadores en contextos similares. Palabras claves: Inglés lengua extranjera; trabajo de campo; acceso y entrada; México.

\section{INTRODUCTION}

In spite of the recent proposals for innovation in education in Mexico at primary, secondary and preparatory levels, little research has been carried out into the ways that foreign language planning and policies are being implemented in the schools. Data 
concerning the situation before these innovations are scarce and mostly anecdotal, mostly displayed in research reports at BA and MA levels. Since the implementation of the new proposals no rigorous attempt seems to be on the way to build the big picture of language teaching and learning in Mexican state schools, despite the urgent need to discover what is currently happening in the Mexican context. One very important requisite to be able to study teachers and students in action and hear their voices about the teaching and learning that is going on in foreign language classrooms is to obtain the necessary permissions to get into the research site.

Entry tends to be a neglected aspect of research methodology. Valuable first-hand accounts about the entry process in social studies are given by Hammersley and Atkinson (1995: 54-79). Also Delamont (2002: 97-112) provides enlightening examples of the process that different researchers went through to negotiate access to different 'formal'/ 'structured' or 'public/unstructured' settings. She also highlights the lessons to be learnt from these researchers' experiences. However, in the field of TESOL, Richards (2003: 120-129) laments the fact that 'the negotiation of entry is an aspect of research that is sometimes neglected in discussions of qualitative methodologies and yet it is the element upon which so much depends'.

One would assume that researchers want to give full accounts of the unique entry process into their research site, which is often time-consuming, full of hurdles and dead ends. In many cases, the gatekeepers - those in power to grant, delay or deny permission - make entry difficult since they first and foremost want to protect the interests of their organization:

Some writers convey the sense that obtaining access was seamless and effortless, that the researcher simply decided what site or sites she or he wished to study, asked for permission, and received it with nary a rejection (e.g., Fine, 1996: 2405 ). But the preponderance of evidence suggests that organizational gatekeepers tend to deny and delay researchers because they are concerned - not unreasonably from their point of view - about the uses to which the research data will be put. (Smith, 2001: 226)

Though the issue of how access was obtained in fieldwork has often been downplayed, taken for granted or ignored completely, especially in the field of TESOL in Mexico, it is nevertheless a key issue, since without entry, no data can be collected.

For instance, in the few published ethnographic studies carried out in secondary and preparatory schools in Mexico, entry has received only brief comments (e.g., Guerrero 2000: 7) or has not been mentioned at all (e.g., Herr and Anderson, 1997; Guerra, 2000; Díaz, 2001). In view of this, questions can be raised, such as the following: Why do so few Mexican researchers explain how they entered the educational research sites? Why do the few researchers who actually do include an explanation in their research accounts often present this process as a simple and straightforward fact? Possibly the following lines of thought can throw some light on these queries.

First, it seems that in our regional and national educational context, the ethical issue of asking research participants for their consent is not always compulsory in the institutions where these researchers are affiliated. The regional and national journals where these 
research accounts are being published do not require it, either. This situation is quite different from that in the US, and other first-world countries, where institutional review boards (IRB) have taken care of «greater protection and informed consent to human subjects who participate in research» (Johnson and Altheide, 2002: 59) since the 1970s. Currently, these IRBs have come under attack. For example, they are now said to «represent a major bane and obstacle to active researchers» (Adler and Adler, 2002: 5) and to be causing qualitative researchers to be subjected to «an unsettling form of colonization» (Van Den Hoonaard, 2002: 5) by the traditional research ethics boards in their institutions who still favour the scientific research paradigm. In the US - as in other first world countries - researchers are subjected to the rules and regulations of the institutions of their affiliation: «University-based researchers and scholars no longer plausibly claim independence from their state patrons and sponsors» (Johnson and Altheide 2002: 61). The basic tension can be explained by the existence of two models of ethics currently in practice in social science research (Denzin, 1997 in Scheyvens et al., 2003: 140). The first of these, based on the work of Kant, takes an absolutist view on ethics, saying that they have to be adhered to under all circumstances. The second, resulting from postmodern, feminist philosophy, rejects the rational objectivity of the first and claims that researchers «should be knowledgeable about professional codes of ethics but in the end, ethical decisions should be based on reasoned beliefs regarding the 'goodness' or 'correctness' of what to do» (Scheyvens et al., 2003: 141). Whether universities or schools in our context decide, or not, to institutionalize similar ethics research boards does not prevent the national researchers from being ethical: «While a general code of ethics which covers informed consent, confidentiality, and conflicts of interest, can provide you with useful guidelines, in many cases it is your personal characteristics - ideally a combination of integrity, maturity and sensitivity to the local cultural context (de Laine, 2000: 28) - which you will need to call on to guide you» (Scheyvens et al., 2003: 166). In our opinion, the crux of the matter is that quality of research does not correlate with the existence of ethics research boards, per se, but depends on the rigour of its design, data collection and analysis and how truthful it is reported.

In the area of TESOL/ELT in Mexico, few researchers seem to be worrying about asking their participants for consent. This is common practice in research-active countries with ethics research boards. In our context, it may well be that the researchers who were initiated in this research practice in English-speaking or other first-world countries (because of their studying an MA or a $\mathrm{PhD}$ ) continue to do so, while those researchers who did not go abroad for post-graduate studies simply do not follow this practice.

Another factor to be taken into account is the difference in culture between these first-world countries and ours, in as far as the more literate societies have grown more familiar with the written code, while Mexico is said to have more of an oral culture. In fact, from our first-hand experience, asking for consent in writing often puts the participants in our context on the defensive. From the experience gained in Basurto's (2010) research, it seems that, rather than ask participants to fill out a written consent form, it may be more useful to orally explain and clarify what the research is NOT about or what the participants are NOT required to do. Rather than abide by externally imposed rules and procedures, it seems crucial to be sensitive to the local norms and expectations (Basurto, 2010). 
As for the second line of thought, plausible insights about the aforementioned queries may also come from the fact that gaining entry into schools has been claimed to be context-dependent.

Even worse, some texts on research carried out in schools may mislead new researchers into thinking that negotiating entry is a simple and straightforward matter as this important aspect of fieldwork has been either played down, taken for granted or ignored completely (Burgess, 1991: 8-9; 1995: 31-52)

If each process of gaining entry is perceived as different, then it could be argued that there is no point in describing it in detail. But this is not so, for two reasons. First of all, sufficiently sensitive, descriptive accounts of the research site and of how entry was obtained may not yield conclusions that can be generalized, but they can certainly feed into research designs in similar settings, either because the research was carried out in the same country or region, or because some of the basic characteristics of the site are similar. Second, these detailed descriptions do more than simply describe the process. They also contribute to the explanation of how the research site functions. They help understand the complexity and uniqueness of the educational system, the school, the classroom. Even when gatekeepers frustrate the entrance to the site, by denying or delaying entry, the gatekeepers' resistances to researchers present a story or set of data about the organization itself» (Smith, 2001: 226), they can expose «deeply held values and interests of the actors» (Burawoy and Lukács, 1992, in Smith, 2001: 226).

This paper aims to contribute to the understanding of entry into the Mexican educational system. After a discussion of the basic concepts involved in the process of asking for permission to carry out research in educational settings, it then tells the story of our first-hand experience of gaining entry into public (and several private) preparatory schools in one city on the east coast of Mexico by starting at the top of the educational hierarchy at state level and working our way down into the actual English language classrooms. The paper finishes by raising some general issues that grew out of our anecdotal experience, which we claim may be helpful for other researchers when approaching their research site in the Mexican educational system.

\section{Gaining entry: Related CONCEPTS}

\section{Gaining entry - gaining access}

Though at first sight, entry and access seem to be synonyms, the literature does make a distinction between these terms. The term entry can be understood as the process of being granted permission into the physical space or to people who are not the actual informants. Entry can be obtained from a person higher up, for example, by means of an official document. The term access, on the other hand, refers to the participants' personal decision to freely take part in the study, in which ethical considerations should be observed (Ball, 1990). As Whyte (1997: 16) emphasizes, when researchers have managed to be 'physically' inside the research site, this does not guarantee that the researcher will be able to gain access to the information he or she is seeking from the actual participants through informed consent. 
Nora M. Basurto Santos and Paula Busseniers $\quad$ Investigating English Language Classrooms...

\section{Informed consent}

The term informed consent means that participants should agree freely and with full understanding of what is going to be required of them and how the information that they provide will be used (Scheyvens, Nowak and Storey, 2003: 142). It has become standard procedure in countries where doing research has become common practice.

Eisner (1991) drew attention to the fact that the concept itself is problematic in field research and explorative studies, where carefully planned research designs are unrealistic:

Thus we all like the idea of informed consent, but we are less sure just who is to provide that consent, just how much consent is needed, and how we can inform others so as to obtain consent when we have such a hard time predicting what we need to get consent about (Eisner, 1991: 215 in Kvale, 1996: 114).

\section{Gatekeepers}

Gaining access to schools and specific classrooms is a very delicate matter, often frustrated by individuals known in the literature as gatekeepers (Becker, 1970 in Taylor and Bogdan, 1984: 20). Similar to what the goalkeepers in soccer do, gatekeepers in research have the power and authority to deny access to their territory and should therefore be identified by the researcher. Usually, in the context of TESOL gatekeepers are school owners, principals, educational officials or even secretaries, "all with their own particular axes to grind and territories to protect» (Richards 1999). Researchers may waste a considerable amount of time trying to negotiate access. Even when access has been initially given, this can still be taken away at a later stage, or dragging feet can indicate it was not given whole-heartedly. Gaining access is definitely not a linear process:

Fieldworkers never know what organizational door will close in their faces, what meeting will be convened to which researchers are spontaneously invited, or what change in organizational fortunes may lead investigators down new avenues of enquiry (Smith, 2001: 227).

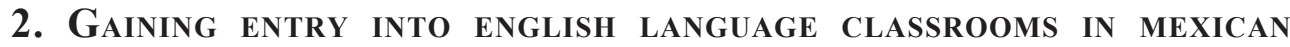 PREPARATORY SCHOOLS: AN ACCOUNT}

The story that we will now tell corresponds to research carried out in a major town on the east coast of Mexico. This research was conceived in response to the oftenexpressed complaint about the urgent need for research into actual practice in real classrooms (Nunan, 1990: 5) and was jointly designed by the local team, made up by the authors of this article and our colleague Barbara Scholes, under the supervision of Keith Richards, then at Aston University. The scope of this qualitative research project was modest and basically aimed at better understanding English teaching and learning in the preparatory schools and identifying instances of successful EFL teaching by the teachers of the public sector in the state. Data were collected in over twenty schools, with forty lessons observed and semi-structured interviews with more than 10 teachers and over one hundred students. Results of the research were presented at national conferences in ELT (Basurto et al., 2000; 2001a; 2001b; 2001c). 
When we first planned the research, we innocently thought that it was going to be a simple matter to enter the schools. All that had to be done was to knock on the door, and we would automatically be invited in with open arms. Reality taught us that it was much more complex than we had originally anticipated. In order to gain entry into the educational system we had to go through a series of stages, moving from the very top, down into each of the participating schools. Adjusting entry procedures to the demands of each of the schools turned out to be a time-consuming and often frustrating process that needed a lot of patience, dedication and tact. This is the story of how it went.

\section{Trying to open the big gate}

In order to comply with the ethical issues of qualitative research as mentioned in the literature (e.g., de Laine, 2000), one of our first decisions was to find the key person(s) from whom to obtain the necessary permissions. This stage turned out to be much longer and much harder than expected; more like a ride on a roller coaster, with moments of great expectation rocketed down into spells of despair. Our original idea to try and make an appointment with the Secretary of Education himself was soon discarded. What was needed, we thought, was contact with a suitable person «high up» in the system to «test the ground». And here came our first stroke of luck. As often happens, it was a third person that helped us make an appointment with the Deputy Secretary, but though one of us had a direct link with this person, our appointment with him was postponed. This was the first of many setbacks that we had not anticipated. When a new appointment was made and all three of us finally met with the Deputy Secretary, we had no difficulty in convincing him to allow us to do research in the schools. He seemed to think that our project was simple, straightforward and doable, and seemed to welcome our intention to find positive characteristics of English teaching in the Preparatory schools and to create a portfolio of activities as a contribution for the teachers.

As has been documented in the literature, knowing a person in the research site is often very important for the gates to open. For example, Hoffman (1980: 46-7) describes how her early efforts as a graduate student failed when seeking access to boards of hospital doctors in Québec, Canada:

Introducing myself as a sociology graduate student, I had very limited success in getting by the gatekeepers of the executive world. Telephone follow-ups to letters sent requesting an interview repeatedly found $\mathrm{Mr} \mathrm{X}$ 'tied up' or 'in conference'. When I did manage to get my foot in the door, interviews rarely exceeded half an hour, were continually interrupted by telephone calls (for 'important conferences', secretaries are usually asked to take calls) and elicited only 'front work' (Goffman, 1959), the public version of what hospital boards were all about.

When one interviewee discovered that he knew members of the researcher's family, things took a very different turn:

The rest of the interview was dramatically different than all my previous data. I was presented with a very different picture of the nature of board work. I learned, for example, how board members used to be recruited, how the executive committee 
Nora M. Basurto Santos and Paula Busseniers $\quad$ Investigating English Language Classrooms...

kept control over the rest of the board, how business was conducted and of what it consisted, and many other aspects of the informal social organization of board work.

This is an example that it is often better to work through people you have a relationship with -or can develop a relationship with- than via letters sent out to various individuals.

The goodwill of the Deputy Secretary seemed very clear to us: he gave us an official booklet with current information about the schools, directors, addresses and phone numbers, which was very useful to us. He also suggested we write an entry request to the Secretary of Education. He explained that he would personally follow this through. We politely waited for some time for the official reply, then made a phone call, the result of which was a new appointment to explain the research project again to the next person down on the hierarchical ladder. We literally waited for weeks, making frustrating phone calls to find out that the appointments were once again postponed. On the day of what we thought was the last of these appointments, several things went wrong. Lightheartedly we directed ourselves to the same office block where we had had our previous meeting. We innocently walked from office to office, asking around for the office of the person we were supposed to meet, until we realized that we were in the wrong building. When it dawned on us that we were supposed to meet in a different building, in another part of town, miles away, we raced through the heavy traffic as best we could, only to find that once we arrived at the correct place, completely out of breath, the person that we were to see was, in fact, out of town. Before our faces could drop, we were also told that he had left instructions for his personal secretary to interview us and find out about our intentions. She gave us the impression that she was assuming the role of the subdirector.

As inexperienced researchers, we did not immediately "read» the role the secretary was playing. She made copious notes of the interview, constantly nodded understandingly. Soon, we realized from the way she handled the interview, the questions she asked and the suggestions she made, that she was not on our side. For example, she suggested that we approach the researchers doing research for the Educational System. She continued that they would certainly invite us into their team to do another research project, because what we were trying to do «had been done before». To avoid conflict, we remained silent, feeling that we were being taken on a ride. We discovered later that these researchers were investigating fields other than foreign languages. Had we been misinformed or had we been misunderstood? Things started to become more blurry when she claimed that it was absolutely essential for us to inform the teachers' union leaders and receive their blessing about the project. The secretary probably thought that we were «spies», or inspectors rather than researchers - a perception also shared by some of the directors and some of the teachers later on. We avoided confrontation by reiterating our good intentions and the care that we would give not to cause offence or problems to those involved in the research. This experience taught us that patience, tact and the art of listening are essential qualities for a researcher to develop. However, there were soon more lessons on developing patience to be received.

After the interrogation, we received another invitation to the Secretary's office to hear about the verdict, but then we were summoned back for a face-to-face meeting with 
the Deputy Secretary himself. More weeks of frustrating phone calls and postponed appointments went by. Then it became known that the Deputy Secretary that we had met long before no longer had this post. Our morale dropped: it seemed we had reached a dead end.

In despair, we turned again to our first contact and asked him for advice, but to our surprise we were informed that the person to be appointed as Deputy Secretary was a very approachable person. We saw a glimmer of light at the end of the tunnel. And on top of that, we were told that we could always go back for help if necessary!

Luckily his help was not needed again, since we soon managed to make an appointment with the new Deputy Secretary, which was not postponed this time, and we were received after waiting only five minutes. The person in question had read our research proposal and the request for entry into the research site, and readily dictated to his secretary an official document addressed to the school directors of the state schools as well as the private preparatory schools. This letter was supposed to be the key to open all the doors. Later on it seemed it was the key to Pandora's box. The official document was ready and signed only two days later.

This last experience had been so positive that it renewed our confidence to think that having been able to convince the authorities, it would be far easier to be understood by the people on the job. We were soon to realize how much we still had to learn.

\section{Knocking on the doors of the preparatory schools}

At first, appointments were made with the directors over the phone. This often seemed unnecessary, so soon we would become bolder and arrive at the school without previous appointments. Then we discovered that this was sometimes regarded as a sign of disrespect, especially by some of the principals of the private schools. Most of the time, it was the head of the school who received us, but sometimes it was the deputy director, and on a few occasions it was the secretary.

Knowing somebody in the school was not always helpful, and we came to realize that a foot in the door sometimes closes the door. In one school, for example, the director was the godfather of the child of one of our team members, but this fact did not make him less apprehensive. In other schools, entry was plainly denied, or simply made very difficult, in spite of the fact that we already had a foot in with one or more of the teachers.

The normal procedure for gaining entry would be as follows. The director would receive one of us in his or her office, and after the introductions and breaking the ice, the purpose of the visit would be explained. At some point, the letter from the authorities would usually be mentioned.

The letter received a variety of reactions. Some directors - though not all - showed genuine interest, and asked for a copy straightaway. Others, on the contrary, had no interest in the letter. It was interesting to see that none of the principals seemed to have received the official letter directly from the authorities, despite the fact that these had assured that they would send it to all the schools in town. In one school, the letter was considered unnecessary. In another school, it was not this official letter, but a letter from our university that helped us.

Soon we started to see the danger of the official letter and we changed tactics. We would emphasize the fact that we had no ties with the educational state authorities, 
hoping to blow away all suspicions about us being spies for the authorities. In many schools - mainly state schools - the letter indeed opened the door, but especially in private schools, the letter would often be received with suppressed annoyance. A plausible explanation for this may be that directors of private schools do not have to pay lip service to the state authorities of the educational system. They do not owe their post to the authorities - as is the case of many directors of state schools. Their worries lie elsewhere, usually with the parents, who pay them.

The interview with the school director normally ended by discussing the procedure for access - unless by now he or she had already decided that access would be denied. Some directors voluntarily offered schedules and promised to notify the coordinators; others passed the responsibility for this to one of their subordinates. Even when they seemed friendly and encouraging, they did not always carry out what they had promised. Often, the people in question were not notified, or worse, friendliness was only a guise for dragging feet.

Some directors openly made it clear to us that they were in power. The asymmetric power relationship was achieved in several ways: by keeping us waiting, by denying us an appointment and channelling the request through a subordinate, or by denying entry over the phone rather than in person. In one case, one of us was forced into the role of spectator, while the director and the sub-director noisily aired their grouses about the incompetence of the English teachers that had made their way through their school!

\section{The classroom door ... at last?}

The directors were not the last persons that had to be convinced. In a number of schools, the next person to deal with was the English coordinator, who is also in a position to lock the door forever. One wonders whether this was to discreetly align with the covert disagreement of the principal, or whether to protect themselves in case they were deemed incompetent. Coordinators as gatekeepers were, in fact, the reason why no observations were carried out in a number of schools: they were the ones that closed the door.

Nevertheless, in most schools, we were finally given permission to speak to the teachers themselves who often had to be explained all over again the purpose of our visit. Sometimes, the letter of the authorities had to be pulled out again. Although many teachers readily agreed to cooperate, there were also a lot who would have loved to refuse, but felt that they could not, for fear of losing face. In a desperate attempt to cover up their insecurity, a few would insist to go straight into their classroom. On the way, they would then apologize for whatever we would see in their class and give a number of excuses about why their classes were not very successful.

The teachers aired their insecurity in several ways. One of them expressed that being observed by a native speaker makes (non-native) teachers doubly nervous. She also wanted to know what standards she was going to be compared with (as her school was not «a bilingual» school). In that school teachers openly told us that they had previously been observed by inspectors, and these had given reports on their performance to the director of the school as well as to the educational authorities. Because of this we received a negative reaction towards our research, no matter how hard we tried to convince them that we were not going to evaluate them or write reports. 
In spite of the initial acceptance of many of the teachers, a lot of them did not seem very happy about the situation. Some kept putting off the observation dates that they themselves had scheduled. Others used the telephone to cancel the night before the observation. One even stirred up a bit of trouble to feel entitled to call off the scheduled observation. Some of these teachers' fears were simply fear of losing face in the eyes of the researcher and fear of being reported as incompetent to the principal or to the higher authorities.

\section{InSIGHTS GaIned}

Experiencing first-hand the process of gaining entry into preparatory schools has given us insights into a number of things. Some of these insights simply corroborate the literature, but there are also a number of them that are not specifically dealt with elsewhere and that we feel could be of interest to young or prospective researchers.

Researchers who want to investigate classrooms have to go through a «hierarchy of consent» (Dingwall, 1980), that is, they have to ask for permission to a number of possible gatekeepers, usually starting with those at the top and ending with those at the bottom.

Hierarchies classify people into categories according to the amount of authority or power they have. The state educational authorities, for example, are the ones at the top of the hierarchy while the classroom teachers, or rather; the students are the ones at the bottom. It may seem common sense that it is the higher educational authorities, those at the top, that have the most power. The issue is, nevertheless, not as simple as this. In our research, the higher educational authorities acted as the most important gatekeepers to grant, deny or delay entry to the system. Yet, is this always so? In our view, this is not the case. In the context of our own research, it was only because we had decided to start at the top of the educational ladder. Now that we have been through the experience, we realize that there were other options. We could have started straight at the school level, for example, or with the coordinator, or with the classroom teacher. These choices are open, depending on how the research is being presented to the participants, or rather, where the emphasis is being put in the representation of your research (Richards, 2003).

From a different perspective, there is also the difference between state and private systems that has to be taken into account. When trying to do research in the private sector, the gatekeepers with the highest power are not really the educational state authorities, as we can infer from the little success we had to get into the private schools. The directors' perceived commitment to the system may differ, which in turn may influence the decision about whether they allow the researcher into the school or not. In state schools, the principals are appointed by the higher authorities, so that they are accountable to them, and therefore also often feel that they owe a certain degree of loyalty to them. As a consequence, these principals may feel that they could not act against the official permission which was given in the form of a letter. In private schools, though, the principals have other interests to protect. They sometimes own the school, or have to account to a board of trustees; they therefore feel that they have to defend the prestige 
of their schools and the financial interests of the owners of the school. If they feel that some kind of criticism about the quality of their school is implied, they will try to save face. Having a researcher peeping into their classrooms can easily be interpreted as a hint that something is not up to standard. Directors of private schools can act as very powerful gatekeepers.

A useful way to understand the complexity of getting into educational research sites is the distinction between entry and access. If a researcher wants to obtain permission to observe actual lessons, for example, the choice is there to start by gaining entry via the official authorities, as seen above, and then approach the directors. Yet, this alone is not enough. Entry is about the official permissions, the letters that grant permission, the signature received. Entry is about the authorities. Access is of a different kind. Usually, the gatekeepers who give, deny or delay access do not write official letters, although they may pronounce into a tape-recorder that they agree to the research, or sign a letter of consent. As already discussed in the introduction to this article, in Mexico letters of consent are often threatening, because they seem to commit the participant to the participation in the research. Depending on the exact research site in Mexico, not everybody is happy to sign a letter of consent. Participants in university contexts will certainly be more ready to do so, but what if the research is seeking participation from teachers and/or students in a rural school, an underprivileged school where literacy practices are rather uncommon and where nobody has actually every seen a «researcher.» Basurto makes the following reflections about her own experience during her research (2010: 87):

... researchers cannot and should not overlook the fact that dealing with people is a very sensitive and delicate matter. Two important issues I've learnt from my field work carried out for this study worth bearing in mind are: no matter how many 'official documents' of consent to entry a research site you have been granted, the only thing you can be sure of is that you have been allowed to get into the site but not along with the people in it; some people feel threatened when they are observed or interviewed because they may think the researcher's interest is to judge them and not to understand them, especially if they are in a position (co-ordinator) in which they are likely to be held account for the success but most importantly for the failure, of their work.

If the authorities, the principals, the coordinators or the teachers for some reason are unwilling to allow entrance into the classrooms, then the research is invariably in danger, but to differing degrees: if the authorities refuse, then the research will not take place at all; if the principal refuses, the researchers will have to look for a different school to go to; if the coordinators or teachers refuse, or say «yes» and then keep postponing, there is still no access to the classroom, in spite of the permissions given higher up. Technically speaking, the teachers would not be able to refuse access to their classroom if the coordinator, the principal (and therefore also the higher authorities) had already given permission to do so.

The higher up the gatekeepers are, the more dramatic their denial, because their refusal cuts off the research altogether. The lower down the line they are, the more 
frustrating it is for the researcher if gatekeepers happen to say no, because more time and effort have been invested. Even if the gatekeeper highest in the line grants permission, the next gatekeeper down the line can still deny permission.

Apart from the aforementioned loyalties and interests, there is also the issue of how the next gatekeeper interprets the decision taken by the one above:

Some individuals and groups have little or no knowledge of social research; and, partly, as a result, field researchers are frequently suspected, initially at least, of being spies, inspectors, missionaries, etc.»

(Hammersley and Atkinson, 1995: 89)

Principals of private schools may feel that the educational authorities do not have the right to interfere in their territory, and therefore deny access to their schools. Classroom teachers may interpret the permission given by the authorities or by the principal as a clever way of keeping tabs on them and therefore - if given a chance - decide to keep the spies out of their classrooms.

The decision taken by the gatekeepers can also be influenced by affiliation. If the researchers are members of an institution, such as a university, this may sometimes be a hindrance because they are perceived as «threatening» or sometimes as a help, because they are expected to be helpful and give advice. When researchers are perceived by the teachers as people who can be helpful, this may have negative as well as positive aspects. Especially when dealing with the teachers, researchers may try very hard not to influence the teacher' $s$ responses, but the teachers may nevertheless be expecting advice, and this can be a difficult line to tread.

Personal affiliation of the gatekeepers with the institution of the researchers may also incline them to either open the door, or close it. The new Deputy Secretary, for example, had been employed by our university and was therefore immediately in favour of the research project in the preparatory schools. Teachers who were ex-students of our School sometimes reacted immediately in favour of being observed, while others did not. Affiliation of the gatekeepers with their own institution is not necessarily a point in favour and should be treated with kid gloves.

When dealing with the gatekeepers, one should also take into account that gatekeepers can sometimes misunderstand the information that they are given by the researchers. One of the difficulties in negotiating entry is precisely to provide the correct amount of information about the research and check that it has been understood correctly. However, it may prove that the more information the researcher provides, the more this can be used by the gatekeeper to deny entry.

One of the things the researcher must be constantly aware of in negotiation is the extent to which the gatekeeper might be able to manipulate access, and the more information the researcher provides, the greater the danger of this (Richards, 1999).

As a summary of the research issues dealt with so far, there are four important problems that a researcher may have to deal with when trying to gain access. The first problem refers to the distortion of the research sample that researchers face when too 
many participants refuse to cooperate. The second problem is the danger of giving out too much information about the research, thus compromising the research because the participants know what the researchers are looking for and therefore act accordingly. The third danger occurs when researchers want to remain neutral and avoid expressing their own beliefs for fear of influencing the participants, creating demands for information down the line. The fourth problem arises when participants see the researchers as a threat to them and therefore show a defensive response (Richards, July 2001, personal communication).

\section{Conclusion}

The process of gaining entry into preparatory schools in a major town on the east coast of Mexico provides insights into a number of issues for gaining entry into educational settings. The main issues deal with contact-making, arrangement of consent, the representation of the research, establishing the researcher's role and the building of relationships with the participants.

As far as contact-making is concerned, the experience gained in the east-Mexican context indicates that personal contact opens many doors - but not all. This confirms Richards' statement: 'All the evidence of the literature points unequivocally to the conclusion that it is personal contact which is likely to open doors' (2003: 120). He further illustrates this with an example from his own experience:

My experience when looking for a school in which to research staffroom talk underlies the value of personal contact, however unexpected. I was interested in a particular type of staffroom and had made contacts with various institutions around England, some nearly 200 miles from my home, but without success. Eventually, at a conference in Mexico, I met the owner of a school that was exactly what I was looking for - and it turned out to be just a five-minute walk from my home. (ibid.: 121)

When trying to arrange consent, gatekeepers can help or hinder the researcher's entrance into the schools. Gatekeepers can go in many disguises: even people lower down on the educational ladder may use their power to facilitate or obstruct the research. Therefore, all the possible gatekeepers should be given their due. Sometimes, a pay-off for the participants may influence their decision to let in the researcher. This is in line with Richards (1999) when he affirms that access is influenced by the way information obtained during the research is going to be used by the researchers.

Researchers who explain their research to the participants may avoid misinterpretations but explaining too much or too little can be equally harmful for the way participants build their representation of what the researcher is trying to achieve.

The way that the role of the researcher is constructed in the eyes of the participants is never a simple or straightforward process. Even when the researchers think that their role in the research site is crystal clear to them, the participants - from top to bottom - might still see things in a different light.

Last, it is well worth investing time and energy in building rapport with the participants to gain acceptance. Having good people skills and being able to establish a comfortable working relationship are factors that promote the teachers' acceptance. Most of them feel 
threatened by observers peeping into their classrooms, asking questions about their lives. By showing interest in what they have to say, no matter how irrelevant it seems, they become more confident.

\section{REFERENCES}

Adler, P.A. and Adler, P. (2002). «Do university lawyers and the police define research values?», in W.C. Van Den Hoonaard (ed.), Walking the Tightrope: Ethical Issues for Qualitative Researchers, 34-42.

Ball, S.J. (1990). «Self-doubt and soft data: Social and technical trajectories in ethnographic fieldwork ", in International Journal of Qualitative Studies in Education, 3, 2: 157-171

Basurto, N., Busseniers, P. and Scholes, B. (2000). «In search of successful classroom practice in Preparatory Schools». Paper presented at the XXVII National Mextesol Convention, Aguascalientes, Ags., Mexico, 19-22 October.

Basurto, N., Busseniers, P. and Scholes, B. (2001a). «Doing research in educational settings: The issue of gaining entry». Paper presented at the XV Foro de Especialistas Universitarios en Lenguas Extranjeras, Veracruz, Ver., Mexico, 22-24 May.

Basurto, N., Busseniers, P. and Scholes, B. (2001b). «Research into classroom practice in Preparatory Schools: A report». Paper presented at the XXVIII National Mextesol Convention, Puebla, Pue, Mexico, 11-14 October.

Basurto, N., Busseniers, P. and Scholes, B. (2001c). «Doing qualitative research in language classrooms». Paper presented at the XI Semana de la Investigación Científica, Facultad de Idiomas, Universidad Veracruzana, Xalapa, Ver., Mexico, 15-19 October.

Basurto Santos, N. (2010). Transition in EFL from Secondary to Preparatory in Mexican State Schools: Participant Perspectives. Biblioteca Digital de Humanidades. Dirección General del Área Académica de Humanidades: Xalapa: Universidad Veracruzana, Mexico. Available from: http://www.uv.mx/bdh/documents/Libro1Basurto.pdf, accessed 1 July 2010.

Becker, H. S. (1970). Sociological Work: method and substance. USA: Aldine, Publishing .Co.

Burgess, R. G. (1991). «Sponsors, gatekeepers, members, and friends», in W.B. Shaffir, and R.A. Stebbins (eds.), Experiencing Fieldwork: An Inside View of Qualitative Research. Thousand Oaks: Sage.

Burgess, R.G. (1995). In the Field. An Introduction to Field Research. London: Routledge.

Burawoy, M., and Lukács J., (1992). The Radiant Past: Ideology and Reality in Hungary's Road to Capitalism. Chicago: University of Chicago Press.

de Laine, M. (2000). Fieldwork, Participation and Practice: Ethics and Dilemmas in Qualitative Research. London: Sage.

Delamont, S. (2002). Fieldwork in Educational Settings. Methods, Pitfalls and Perspectives (2nd ed.). London: Routledge Falmer.

Díaz Pontones, M. (2001). Estrategias de Enseñanza en la Escuela Secundaria: Un estudio etnográfico. México: CINVESTAD, Centro de Investigaciones y Estudios Avanzados del Instituto Politécnico Nacional.

Dingwall, R. (1980). «Ethics and Ethnography», in Sociological Review, 28, 4: 871- 891.

Guerra Ramírez, M.I. (2000). «¿Qué significa estudiar en el bachillerato? La perspectiva de los jóvenes en diferentes contextos socioculturales», in Revista Mexicana de Educación Educativa, 5, 10: 243-272.

Eisner, E.W. (1991). The Enlightened Eye. New York: Macmillan. 
Nora M. Basurto Santos and Paula Busseniers $\quad$ Investigating English Language Classrooms...

Fine, G.A. (1996). Kitchens: The Culture of Restaurant Work. Berkeley, CA: University of California Press.

Goffman, E. (1959). The Presentation of Self in Everyday Life, in J.E. Hoffman (1980).

Guerrero Salinas, M.E. (2000). «La escuela como espacio de vida juvenil. Dimensiones de un espacio de formación, participación y expresión de los jóvenes», in Revista Mexicana de Investigación Educativa, 5, 10: 205-242.

Hammersley, M. and Atkinson, P. (1995). Ethnography (2nd ed.). London: Routledge.

Herr, K. and Anderson, G.L. (1997). 'The cultural politics of identity: Students' narratives from two Mexican secondary schools', in Qualitative Studies in Education, 10, 1: 45-61.

Hoffman, J.E. (1980). «Problems of access in the study of social elites and boards of directors», in W.B. Shaffir, R. A. Stebbins, and A. Turowetz, (eds.), Fieldwork Experience: Qualitative Approaches to Social Research. New York: St. Martin's Press.

Johnson, J.M. and Altheide, D. (2002). «Reflections on professional ethics», in W.C.Van Den Hoonaard (ed.), Walking the Tightrope: Ethical Issues for Qualitative Researchers. Toronto: Toronto University Press, 59-69.

Nunan, D. (1990). «Second Language Classroom Research», available from: http://www.ericdigests.org/ pre-9216/second.htm, accessed 24.January, 2005.

Richards, K. (1999). Investigating Interaction in Context. Birmingham: Aston University.

Richards, K. (2003) Qualitative Inquiry in TESOL. London: Palgrave.

Shaffir, W.B. and Stebbins, R.A. (eds.), (1991). Experiencing Fieldwork: An Inside View of Qualitative Research. Thousand Oaks: Sage.

Scheyvens, R., Nowak, B., and Scheyvens, H. (2003). «Ethical issues», in R. Scheyvens and D. Storey (eds.), Development Fieldwork. A Practical Guide. UK: Sage, 139-166.

Smith, V. (2001). «Ethnographies of work and the work of ethnographers», in P. Atkinson, A. Coffey, S. Delamont, J. Lofland and L. Lofland (eds.), Handbook of Ethnography. Thousand Oaks: Sage, 220-233.

Taylor, S.J. and Bogdan, R. (eds.), (1984). Introduction to Qualitative Research Methods. USA: John Wiley \& Sons, Inc.

Van Den Hoonaard, W.C. (2002). «Introduction: Ethical norming and qualitative research», in W.C.

Van Den Hoonaard (ed.), Walking the Tightrope: Ethical Issues for Qualitative Researchers. Toronto; Toronto University Press, 3-16.

Whyte, W.F. (1997). Creative Problem Solving in the Field. USA: AltaMira Press. 